\title{
EDITORIAL
}

\section{A FORÇA DA CIRURGIA NACIONAL}

\author{
Luiz Arnaldo Szutan \\ Mestre do Capítulo de São Paulo \\ Colégio Brasileiro de Cirurgiões
}

O Colégio Brasileiro de Cirurgiões tem dentre suas responsabilidades 100 números de atividades. As mais significativas estão no âmbito de reciclagem médica e, tanto o Diretório Nacional quanto os Capítulos realizam anualmente inúmeras atividades, com a finalidade de permitir ao cirurgião brasileiro a atualização constante e a troca de informações científicas.

De todas as atividades, nosso Congresso, realizado bianualmente em nível nacional, sem dúvida é a mais significativa. $\mathrm{Na}$ era da informática e das informações a distância, qüestiona-se o valor destes encontros e as perspectivas de sua manutenção a médio e longo prazos.

Em julho último, em São Paulo, foi realizado o XXIV Congresso Brasileiro de Cirurgia. Os resultados foram expressivos. Sob qualquer ângulo que procuramos analisar, o evento pode ser considerado um sucesso.

Quatro mil e quinhentos cirurgiões de todos os Estados brasileiros se inscreveram no Congresso. Seis Sociedades de Especialidades Cirúrgicas (Urologia, Cirurgia Vascular, Cirurgia Plástica, Cirurgia de Cabeça e Pescoço, Cirurgia Torácica e Cirurgia Pediátrica) se associaram ao Colégio Brasileiro de Cirurgiões para a realização de Simpósios de Especialidades.

Esta ação conjunta se reveste de grande importância, por permitir o acesso dos cirurgiões gerais às informações mais recentes das especialidades e à integração com o Colégio Brasileiro de Cirurgiões.

Setecentos palestrantes nacionais apresentaram, de maneira diferenciada, seus conhecimentos específicos em praticamente todos os tópicos da moderna cirurgia e, ao lado de 15 professores estrangeiros dos mais destacados internacionalmente em suas áreas de especialidade, tornaram as mais de 250 sessões científicas numa visão bastante adequada daquilo que se pratica neste momento em termos cirúrgicos. Mais de 900 trabalhos científicos foram apresentados em Sessões de Temas Livres, Vídeos e Posters, demonstrando o entusiasmo de nossos colegas em apresentar a produção científica nacional em nível cirúrgico.

Noventa empresas estiveram presentes com seus produtos e lançamentos em cirurgia - Feira de Exposições MédicoHospitalares. E esta foi uma demonstração de respeito e confiança destas entidades, na importância do cirurgião nacional, quer seja na prática médica ou no desenvolvimento da assistência médica prestada aos nossos pacientes.

No âmbito político, na Sessão Solene do Congresso, contamos com as presenças do Ministro da Saúde, Governador do Estado de São Paulo, Secretários Estaduais da Saúde e Promoção Social e Municipais da Administração, além dos Presidentes da Associação Médica Brasileira, Conselho Regional de Medicina e Associação Paulista de Medicina.

Este relacionamento político será, sem dúvida, de grande utilidade quando assuntos como política de saúde, mercado de trabalho, formação médica, remuneração médica tiverem de ser tratados sob a égide do Colégio Brasileiro de Cirurgiões.

As inúmeras atividades sociais foram bastante prestigiadas e permitiram um agradável convívio de cirurgiões e acompanhantes, demonstrando a amizade e o respeito que nos conglomera.

A repercussão na mídia foi significativa, com intensa divulgação das atividades, e esta preocupação se justifica pela necessidade do aumento da confiança da população brasileira com relação à pratica cirúrgica ora exercida no Brasil. E, felizmente, foi possível obter um resultado financeiro positivo (o balanço completo será oportunamente apresentado no boletim informativo para conhecimento de todos), que, apesar de não ser tópico de relevância, é importante para demonstrar que atividades científicas bem conduzidas colaboram também financeiramente com o Colégio Brasileiro de Cirurgiões.

Perspectivas Cirúrgicas para o Século XXI foi o tema central, e não tenho dúvidas de que o novo século será repleto de evoluções no âmbito cirúrgico-tecnológico, como ficou claramente demonstrado no Congresso, com forte impacto na assistência médica. $\mathrm{O}$ que nos enche de orgulho e esperança, porém, é que a grande perspectiva continuará sendo a competência, responsabilidade e o humanismo do cirurgiões brasileiro e do nosso Colégio Brasileiro de Cirurgiões. 